\title{
MODELLING IMPACT OF URBAN-RURAL INCOME CONVERGENCE IN THE EU
}

\author{
Astra Auziņa-Emsiṇa, Velga Ozoliṇa \\ Riga Technical University, Latvia \\ astra.auzina-emsina@rtu.lv
}

\begin{abstract}
Urban-rural income convergence provides an opportunity to reduce the income inequality, ensuring cohesion and increasing economic output. The results show that urban-rural income convergence is a continuous tendency in the EU; the urban-urban income gap declines - rural population received $79 \%$ of net income of population living in cities in 2017 (in 2010 it was 69\%). The rural population accounts for $27.3 \%$ of the EU and any changes have notable impact on the rest of the economy. Nationally the urban-rural income convergence dramatically differs amid the EU countries. In order to model an impact of urban-rural income convergence, a comparative-static approach that involves an input-output model is applied. Two scenarios are estimated for Latvia's economy: rural net income in Latvia is assumed to be $89 \%$ of cities net income (as in the Euro Area average) in both scenarios, in the first one the saving rate is constant; in the second rural households anticipate the additional net income as a gift (saving rate for extra net income is equal to zero). The results of the first scenario argue that households final demand expenditures increase by $4.5 \%$, output by $2.7 \%$. The largest increase of output is modelled in chemical products $(8.9 \%)$, paper products $(8.7 \%)$, electrical equipment $(6.2 \%)$, pharmaceutical products $(6.1 \%)$, textile $(5.8 \%)$ industries. In the second scenario, the output increase: $3 \%$. The results certify that the increase and convergence of income in rural areas are important even in advanced economies, such as the EU countries. The national and EU policies are welcome and can give notable impact on economic growth.
\end{abstract}

Key words: modelling, urban-rural income, income convergence, input-output.

\section{Introduction}

Urban-rural income convergence provides an opportunity to reduce the income inequality, ensure cohesion and increase in economic performance and output regionally, nationally and in the EU. Distribution of population (and consequently income etc. data) by degree of urbanisation is important and offers valuable evidences for wide audiences as local municipalities, national governments, policy makers, companies and business organisations, education, scientific and research institutions and other organisations non-governmental etc. institutions. However, the effect and scale of urban-rural income converge process have not been determined.

Findings of other authors are controversial as many authors specialize in the urban-rural income gap in emerging economies for example, (Sicular et al., 2007) researched urban-rural income gap and its factors in China; (Zhang, Chen, \& Zhang, 2012) examined the urban-rural income disparities in China in the long run; (Chen \& Sun, 2014) researched and estimated the urban-rural income polarisation effect on the economic growth in China) and the results cannot be applied to the EU countries. The studies on advanced economies include a lot of national specifics as (Breau \& Saillant, 2016) on Canada's rural income disparities by regions; and the research on Greece's economic performance of localities due to local income distribution (Prodromidis, 2008) that ensure valuable findings nationally but have limited application options in other cases and other countries. Many authors investigate the urban-rural income issue in the context of migration from rural areas to urban areas, as well as international migration). Based on the performed analysis of 65 countries, Young (Young, 2013) argues that one out of every four or five individuals raised in rural areas moves to urban areas as a young adult in order to increase net income and actually earns more than rural population that has not migrated. These issues are definitely linked and majority of countries continues to experience ruralurban migration process and the share of population living in cities increases.

The aim of the research is to model an impact of urban-rural income convergence on the national economy. For this purpose a comparative-static approach that involves an input-output model and scenarios, is applied. The research involves the analysis and detection of current trends in the EU regarding urban-rural income volume and dynamics focusing on urban-rural income convergence, inputoutput model building, elaboration of scenarios assumptions, and modelling the results. The analysis and findings suggest that sophisticated analytic and modelling tools give precise and valuable results.

\section{Materials and Methods}

Despite the common understanding, the definitions of rural and urban (as cities) areas are various and different. Hence, initially, the rural and urban areas definition analysis is performed. According to the definition applied by Eurostat (Eurostat, 2019), the degree of urbanisation classifies local administrative units as cities (otherwise referred to as densely populated areas), towns and suburbs (otherwise referred to as intermediate density areas) or rural areas (otherwise referred to as thinly populated areas) 
based on a combination of geographical contiguity and population density, it is based on and measured by minimum population thresholds applied to 1 $\mathrm{km}^{2}$ population grid cells; consequently each local administrative unit belongs exclusively to one of these three classes.

The territorial classifications or typologies have been changed over the time in the EU. This problem has been detected by the EU policymakers and it is admitted that rural and urban areas concepts are used by a wide range of policymakers, researchers, national administrations and international organisations such as the Organisation for Economic Cooperation and Development (OECD), the UN and the EU (Dijkstra \& Poelman, 2014). These two concepts are readily understood by the society, but a clear definition at the international level has remained elusive (Dijkstra \& Poelman, 2014). Some international organisations and institutions completely rely on national definitions and compare the countries analysed on the basis of various typologies. As a result, it is impossible to ensure the data comparability and make regional (multi-national) or global conclusions on these essential issues.

The performed statistical data analysis and comparison of the Eurostat database and national statistical bureaus revealed significant data differences. Mainly, it is due to the differences in nationally applied territorial typologies, in other words, rural and urban areas nationally are defined differently. For example, in the Central Statistical Bureau in Latvia the share of population living in rural areas is stable (and fluctuates minimally in range of $31.7-32.5 \%$ ) in 2005-2017 (Central Statistical Bureau of Latvia, 2019), but in Eurostat data on Latvia the share of population living in rural areas has changed significantly - from $52.7 \%$ in 2005 to $37.1 \%$ in 2017 (Eurostat, 2019). The same differences are detected by analysing data of national statistics offices of Lithuania (in 2005-2017 rural population share is $32.7 \%$ to $33.4 \%$ (Statistics Lithuania, 2019)) and Estonia (36.5\% to $37.1 \%$ in 2012-2017 (Statistics Estonia, 2019)). This is an important point as Eurostat database includes data on income and expenditure, dwellings etc. on the basis of above-mentioned classification of rural and urban areas. If the national statistics are so different from the Eurostat data, new questions and new research directions for further studies arise; however, in this research the Eurostat database is selected as the core data source that ensures the data comparability in time and internationally within the EU. As a result, in the research the Eurostat territorial typologies are applied.

The research is based on the EU data and Eurostat classification. In general, in statistics according to Eurostat (Eurostat, 2019) urban areas refer to an aggregate composed of information covering cities as well as towns and suburbs (in other words, densely populated areas and intermediate density areas). An opposite concept is rural areas including thinly populated areas as stated before.

The research period is 2005-2017 (or till latest statistics available). Urban-rural income convergence is analysed on the basis of Median equivalised net income and Mean equivalised net income in 20052017 by the degree of urbanisation in the EU.

Income can be spent as a private consumption expenditure or saved (saving formation). Eurostat has published valuable experimental statistics on median saving rate by the degree of urbanisation that computed a ratio of savings to disposable income (Eurostat, 2017). This indicator gives a more sophisticated insight in actual urban-rural income, welfare and saving formation activity. However, as the data are experimental statistics, they are strongly limited and currently the data are only available on one year (2010). It offers valuable information for static analysis, but it is impossible to analyse dynamics or perform comparative-static analysis.

Household expenditures are mainly determined by net or disposable income subtracting savings created in the research, households final demand expenditures are applied in scenarios analysis in the input-output model.

The input-output model includes the basic identities that ensure the equilibrium in the economy (Equation (1) and Equation (2)):

$$
\mathrm{x}=\mathrm{Ax}+\mathrm{y},
$$

where $\mathrm{x}$ - output (vector),

$\mathrm{Ax}$ - intermediate consumption (matrix).

$y$ - final demand (vector).

Latvia is amid countries that elaborate product-byproduct symmetric input-output tables according to CPA classification.

Therefore, A is a matrix of technical coefficients, where each element aij corresponds to the volume of intermediate input of product i products to produce a unit of output of product $j$. Technical coefficients represent the direct cost structure of production of product $\mathrm{j}$.

$$
\mathrm{x}=\mathrm{By} \text {, }
$$

where B - Leontief inverse (matrix), computed by Equation (3):

$$
\mathrm{B}=(\mathrm{I}-\mathrm{A})^{-1} \text {, }
$$

where I - identity matrix.

The use of primary factors $(\mathrm{F})$ depends on the technology (technical coefficients of primary factors, showing the quantity of primary factors required per unit of output; L) and output of industry $x$ (Equation (4)): 


$$
\mathrm{F}=\mathrm{Lx}
$$

The impact of urban-rural income convergence is modelled as the scenario analysis applying inputoutput model. In this research, the impact and the socalled what-if scenarios are evaluated in short term and medium term hence technological coefficients are constant. The what-if scenarios allow to estimate the quantitative effect of a certain (or given) change in the economy.

The research data analysis covers the whole EU, but modelling is executed on the case of one EU country - Latvia. The method and the scenarios are applicable to the EU countries facing similar research questions.

\section{Results and Discussion}

Urban-rural income convergence is a continuous process that is observable and assessable in a relatively long term in the EU. In 2017, Mean and median equivalised net income data by the degree of urbanisation are analysed and each indicator has its strengths. In 2017, mean equivalised net income in rural areas in the EU 28 countries was 16.75 thsd. euros or $80 \%$ of mean equivalised net income in cities. So on average a person living in rural area received net income that is equal to $80 \%$ of net income of cities inhabitant. The research aim is to evaluate the income convergence. And hence dynamics and time-series are more important than one year observation that can be biased by various economic, social, political etc. factors. The results of mean equivalised net income in rural areas as percentage of mean equivalised net income in cities in 2005-2017 reveals a stable and constant trend of the urban-rural income convergence and the socalled urban-rural gap has diminished (Table1).

As mean indicators in economics regarding income, wages etc. have some inbuilt biases (weaknesses) also median equivalised net income by the degree of urbanisation is analysed in order to have more detailed and representative results. The median equivalised net income statistics show lower absolute values regarding the income (as in 2017 median equivalised net income in cities in the EU was accounted for 17.93 ths. euro, but in rural areas -14.96 thsd. euro or $83 \%$ of cities net income (Table 2)), but urban-rural income convergence is observable as a stable and constant trend as well.

Mean equivalised net income by the degree of urbanisation in the EU in 2005-2017

\begin{tabular}{|c|c|c|c|c|c|c|c|c|}
\hline Area & Region & 2005 & 2010 & 2015 & 2016 & 2017 & 2017 vs. 2005 & $2017 / 2005$ \\
\hline & & \multicolumn{6}{|c|}{ euro } & $\%$ \\
\hline \multirow[b]{2}{*}{ Cities } & European Union & 15879 & 18483 & 19853 & 20372 & 20990 & 5111 & $32 \%$ \\
\hline & Euro area & 17196 & 20673 & 21190 & 21721 & 22223 & 5027 & $29 \%$ \\
\hline \multirow{2}{*}{$\begin{array}{l}\text { Rural } \\
\text { areas }\end{array}$} & European Union & 9898 & 12893 & 15998 & 16229 & 16748 & 6850 & $69 \%$ \\
\hline & Euro area & 13219 & 16559 & 18721 & 19000 & 19723 & 6504 & $49 \%$ \\
\hline & & \multicolumn{6}{|c|}{ percentage } & \\
\hline \multirow{2}{*}{$\begin{array}{l}\text { Rural } \\
\text { areas vs. } \\
\text { cities }\end{array}$} & European Union & $62 \%$ & $70 \%$ & $81 \%$ & $80 \%$ & $80 \%$ & $17 \%$ points & $\mathrm{x}$ \\
\hline & Euro area & $77 \%$ & $80 \%$ & $88 \%$ & $87 \%$ & $89 \%$ & $12 \%$ points & $\mathrm{x}$ \\
\hline
\end{tabular}

x-not calculated

Median equivalised net income by the degree of urbanisation in the EU in 2005-2017

Table 2

\begin{tabular}{|l|l|c|c|c|c|c|c|c|c|}
\hline \multicolumn{1}{|c|}{ Area } & \multicolumn{1}{|c|}{ Region } & 2005 & 2010 & 2015 & 2016 & 2017 & 2017 vs.2005 & $2017 / 2005$ \\
\hline \multicolumn{1}{|c|}{ euro } & $\%$ \\
\hline \multirow{2}{*}{ Cities } & European Union & 13626 & 15928 & 16991 & 17515 & 17926 & 4300 & $32 \%$ \\
\cline { 2 - 10 } & Euro area & 14928 & 17883 & 18162 & 18671 & 19174 & 4246 & $28 \%$ \\
\hline \multirow{2}{*}{$\begin{array}{l}\text { Rural } \\
\text { areas }\end{array}$} & European Union & 8832 & 11466 & 14250 & 14594 & 14963 & 6131 & $69 \%$ \\
\cline { 2 - 9 } & Euro area & 11835 & 14781 & 16816 & 17215 & 17761 & 5926 & $50 \%$ \\
\hline $\begin{array}{l}\text { Rural } \\
\text { areas } \\
\text { vs.cities }\end{array}$ & European Union & $65 \%$ & $72 \%$ & $84 \%$ & $83 \%$ & $83 \%$ & $19 \%$ points & x \\
\cline { 2 - 9 } & Euro area & $79 \%$ & $83 \%$ & $93 \%$ & $92 \%$ & $93 \%$ & $13 \%$ points & x \\
\hline
\end{tabular}

$\mathrm{x}$-not calculated 
When urban-rural income differences are analysed on national level within the EU, the conditions are very diverse. In some EU countries, net income in rural areas is even higher than in cities. In the UK, the ratio of the net mean income in rural areas to net mean income in cities was $109 \%$ and in means of the median income $108 \%$ and in Belgium the corresponding ratios were $104 \%$ and $115 \%$ in 2017 (Table 3). This indicates that urban-rural income convergence has taken place and there is no urban-rural income gap. However, the data on Bulgaria, Rumania, and Lithuania indicate that there is a severe income gap between urban and rural population - on average a person living in rural areas received less than $70 \%$ of national net income in cities.

The current analysis gives an insight in the present situation; however, the urban-rural income convergence is more important in the long run. The way the dynamics of urban-rural income gap changes in time reflects the actual urban-rural income convergence. In the majority of the EU countries, the urban-rural income gap has declined and incomes are distributed more equally in the national economies.

The analysis of the statistics on median saving rate by the degree of urbanisation in the EU indicates that saving formation is highly inhomogeneous in the EU in Bulgaria (38.0\%), Estonia (35.3\%), Luxembourg (29.9\%), France (29.1\%), Italy (26.1\%) and Poland (25.1\%), $25 \%$ and more of disposable income was saved (not spent in a certain time period), at the same time - in Greece and Rumania societies used former savings and present-day saving rates were negative $(-9.5 \%$ and $-5.0 \%)$ (Figure 1). The urban-rural saving

Comparison of Mean and Median equivalised net income in rural areas (as share of net income in cities) in the $\mathrm{EU}$ countries in 2005-2017

\begin{tabular}{|c|c|c|c|c|c|c|}
\hline \multirow{2}{*}{ Country } & \multicolumn{3}{|c|}{ Mean equivalised net income } & \multicolumn{3}{|c|}{ Median equivalised net income } \\
\hline & 2005 & 2017 & 2017 vs 2005 (\%points) & 2005 & 2017 & 2017 vs 2005 (\%points) \\
\hline United Kingdom & $123 \%$ & $109 \%$ & $-14 \%$ & $106 \%$ & $108 \%$ & $2 \%$ \\
\hline Belgium & $94 \%$ & $104 \%$ & $10 \%$ & $101 \%$ & $115 \%$ & $14 \%$ \\
\hline Austria & $88 \%$ & $97 \%$ & $9 \%$ & $91 \%$ & $103 \%$ & $13 \%$ \\
\hline Germany & $88 \%$ & $97 \%$ & $9 \%$ & $91 \%$ & $102 \%$ & $10 \%$ \\
\hline Netherlands & $86 \%$ & $97 \%$ & $11 \%$ & $94 \%$ & $100 \%$ & $6 \%$ \\
\hline Denmark & $90 \%$ & $94 \%$ & $4 \%$ & $94 \%$ & $96 \%$ & $2 \%$ \\
\hline Czechia & $88 \%$ & $92 \%$ & $4 \%$ & $93 \%$ & $95 \%$ & $2 \%$ \\
\hline Slovenia & $86 \%$ & $91 \%$ & $5 \%$ & $90 \%$ & $96 \%$ & $6 \%$ \\
\hline France & $86 \%$ & $91 \%$ & $5 \%$ & $87 \%$ & $94 \%$ & $7 \%$ \\
\hline Ireland & $74 \%$ & $88 \%$ & $14 \%$ & $76 \%$ & $91 \%$ & $15 \%$ \\
\hline Italy & $80 \%$ & $87 \%$ & $6 \%$ & $86 \%$ & $91 \%$ & $5 \%$ \\
\hline Finland & $83 \%$ & $86 \%$ & $3 \%$ & $90 \%$ & $91 \%$ & $2 \%$ \\
\hline Estonia & $81 \%$ & $86 \%$ & $5 \%$ & $83 \%$ & $83 \%$ & $0 \%$ \\
\hline Luxembourg & $105 \%$ & $85 \%$ & $-19 \%$ & $110 \%$ & $89 \%$ & $-20 \%$ \\
\hline Greece & $83 \%$ & $82 \%$ & $0 \%$ & $80 \%$ & $82 \%$ & $1 \%$ \\
\hline Sweden & $86 \%$ & $81 \%$ & $-5 \%$ & $91 \%$ & $88 \%$ & $-3 \%$ \\
\hline Latvia & $69 \%$ & $81 \%$ & $12 \%$ & $71 \%$ & $76 \%$ & $4 \%$ \\
\hline Slovakia & $80 \%$ & $79 \%$ & $-1 \%$ & $84 \%$ & $84 \%$ & $-1 \%$ \\
\hline Hungary & $72 \%$ & $78 \%$ & $5 \%$ & $76 \%$ & $75 \%$ & $-2 \%$ \\
\hline Spain & $76 \%$ & $77 \%$ & $1 \%$ & $75 \%$ & $78 \%$ & $3 \%$ \\
\hline Cyprus & $81 \%$ & $74 \%$ & $-7 \%$ & $89 \%$ & $79 \%$ & $-10 \%$ \\
\hline Croatia & $\mathrm{x}$ & $74 \%$ & $x$ & $\mathrm{x}$ & $74 \%$ & $x$ \\
\hline Portugal & $67 \%$ & $74 \%$ & $7 \%$ & $76 \%$ & $82 \%$ & $6 \%$ \\
\hline Poland & $69 \%$ & $72 \%$ & $2 \%$ & $72 \%$ & $76 \%$ & $4 \%$ \\
\hline Lithuania & $65 \%$ & $66 \%$ & $0 \%$ & $67 \%$ & $68 \%$ & $0 \%$ \\
\hline Romania & $\mathrm{x}$ & $56 \%$ & $x$ & $\mathrm{x}$ & $54 \%$ & $x$ \\
\hline Bulgaria & $\mathrm{x}$ & $56 \%$ & $x$ & $\mathrm{x}$ & $60 \%$ & $x$ \\
\hline
\end{tabular}

$\mathrm{x}$-no value available; no data on Malta available. 


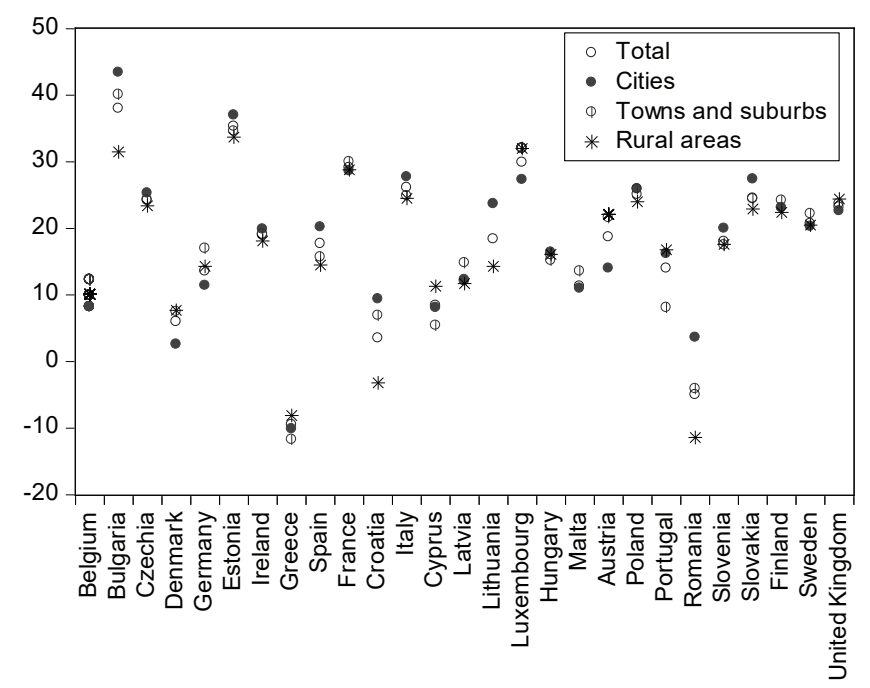

Figure 1. Median saving rate by degree of urbanisation in the EU (\%).

rate analysis indicates that in the EU inhabitants of the cities save relatively more than rural inhabitants - the largest difference between cities and rural population behaviour regarding the saving formation is detected in Romania (in cities median saving rate was 3.6\%, but in rural areas $--11.4 \%$ (difference $15.0 \%$ points), Croatia $(9.4 \% ;-3.2 \%$ and difference $12.6 \%$ points), Bulgaria (43.4\%; 32\%, and difference $11.9 \%$ points), Lithuania (23.7\%; 14.3\%; and difference $9.4 \%$ points), and Spain $(20.2 \% ; 14.5 \%$, and difference $5.7 \%$ points). In Latvia, the saving rate in rural areas was $11.7 \%$, while in cities - towns and suburbs $12.3 \%$ and total saving rate was $-12.1 \%$.

To model the impact of urban-rural income convergence, two comparative-static scenarios are estimated taking into account the above-detected trends and assumptions (based on data analysed) in Latvia's economy:

1) rural medium net income in Latvia is assumed to be $89 \%$ of cities net income (as on average it is in euro area countries), it is assumed that the saving rate is constant $-11.7 \%$. The other indicators (as share of population living is cities, cities net income etc.) are unchanged - ceteris paribus. This scenario involves computing the total rural net income, add to total net income in cities and towns and suburbs, apply saving rate and compute the impact on the economy;

2) rural medium net income in Latvia is assumed to be $89 \%$ of cities net income (as on average it is in euro area countries), it is assumed that the additional income is perceived by rural households as a gift and it is spent fully, hence saving rate is $0 \%$. The other indicators (as share of population living is cities, cities net income etc.) are unchanged - ceteris paribus. This scenario involves computing the total rural net income, add to total net income in cities and towns and suburbs, and compute the scenario impact on the economy;
In addition, two more scenarios were examined but excluded of further modelling - regarding the impact on economy if rural population in Latvia receives the same net income per person as on average in the EU - due to equally fair payments within Common Agricultural Policy etc.; and the impact on economy if rural population in Latvia receives the same net income per person as in Estonia - due to equally regional (neighbouring countries) income convergence (in 2017 net mean income in rural households in Latvia was 7022 euros, but in Estonia 9947 euros (this scenario involved more assumptions regarding the consumer behaviour and spending activities to estimate accurate and credible results)).

The results of the first scenarios estimated by input-output model claim that the impact on the economy is observable and noticeable. In modelling the rural areas and cities population proportions and saving rate are fixed and only income is shocked in order to assess the income convergence effect. As a result, if income in rural areas are $89 \%$ of income in cities instead of $81 \%$ as it was in 2010 (the base year according to the latest input-output tables for Latvia), the total final consumption expenditure of households increases by $4.5 \%$.

Households spend a lot on food, dwelling, transport etc. consumption purposes that can be either domestically produced or imported. It results in $2.7 \%$ increase of national output on various products and services. As households consume and spend on products and services of almost all industries, only the major impacts are analysed in detail. Table 4 shows the modelled full (direct and indirect) impact results of product output changes that are larger than $4 \%$ (output of products with the impact below $4 \%$ are not included in the Table 4). 
Table 4

Modelling results of the first scenario representing sectoral output change (\%)

\begin{tabular}{|c|l|c|}
\hline NACE/CPA CODE & \multicolumn{1}{|c|}{ Product or service } & Impact \\
\hline C20 & Chemicals and chemical products & $8.9 \%$ \\
\hline C17 & Paper and paper products & $8.7 \%$ \\
\hline C27 & Electrical equipment & $6.2 \%$ \\
\hline C21 & Basic pharmaceutical products and pharmaceutical preparations & $6.1 \%$ \\
\hline C13_15 & Textiles, wearing apparel and leather products & $5.8 \%$ \\
\hline C26 & Computer, electronic and optical products & $5.3 \%$ \\
\hline C22 & Rubber and plastics products & $5.3 \%$ \\
\hline C03 & Fish and other fishing products; aquaculture products; support services to fishing & $5.3 \%$ \\
\hline C10_12 & Food products, beverages and tobacco products & $5.2 \%$ \\
\hline A01 & Products of agriculture, hunting and related services & $4.7 \%$ \\
\hline T & Services of households as employers; undifferentiated goods and services produced & \\
\hline L68A & by households for own use & $4.5 \%$ \\
\hline I & Imputed rents of owner-occupied dwellings & $4.5 \%$ \\
\hline S96 & Accommodation and food services & $4.4 \%$ \\
\hline G47 & Other personal services & $4.3 \%$ \\
\hline & Retail trade services, except of motor vehicles and motorcycles & $4.2 \%$ \\
\hline
\end{tabular}

Table 5

Modelling results of the second scenario representing sectoral output change (\%)

\begin{tabular}{|c|l|c|}
\hline NACE/CPA CODE & \multicolumn{1}{|c|}{ Product or service } & Impact \\
\hline C20 & Chemicals and chemical products & $10.1 \%$ \\
\hline C17 & Paper and paper products & $9.9 \%$ \\
\hline C27 & Electrical equipment & $7.0 \%$ \\
\hline C21 & Basic pharmaceutical products and pharmaceutical preparations & $6.9 \%$ \\
\hline C13_15 & Textiles, wearing apparel and leather products & $6.6 \%$ \\
\hline C26 & Computer, electronic and optical products & $6.0 \%$ \\
\hline C22 & Rubber and plastics products & $6.0 \%$ \\
\hline C03 & Fish and other fishing products; aquaculture products; support services to fishing & $6.0 \%$ \\
\hline C10_12 & Food products, beverages and tobacco products & $5.8 \%$ \\
\hline A01 & Products of agriculture, hunting and related services & $5.3 \%$ \\
\hline T & $\begin{array}{l}\text { Services of households as employers; undifferentiated goods and services } \\
\text { produced by households for own use }\end{array}$ & $5.0 \%$ \\
\hline L68A & Imputed rents of owner-occupied dwellings & $5.0 \%$ \\
\hline I & Accommodation and food services & $5.0 \%$ \\
\hline
\end{tabular}

The results of the second scenario estimated by the input-output model claim that impact on the economy is noticeable and relatively similar to that of the first scenario. As a result, if income in rural areas is $89 \%$ of income in cities instead of $81 \%$ that it was in 2010 (the base year according to the latest input-output tables for Latvia), the total final consumption expenditure of households increases by $5.0 \%$ if all additional income in rural households is spent.

As it is assumed that households perceive the additional net income as a gift, it is spent according to the consumption structure - spent a lot on food, dwelling, transport etc. consumption purposes that can be either domestically produced or imported. It results in $3.0 \%$ increase of national output on various products and services. Table 5 shows the modelled full (direct and indirect) impact results of product output change that are larger than 5\% (output of products with the impact below 5\% are not included in the Table 5).

Within the scenario analysis it was detected that there is a large impact on output of two products - Coke and refined petroleum products $(\mathrm{C} 19)$ due to the fact 
that it is almost completely import based industry and any, even minor, changes generate unreasonably high changes but in absolute figures the change is minor, and Mining (B) as it is relatively small production that is accompanied with significant changes in stocks and inventories (in final demand formations).

\section{Conclusions}

The findings demonstrate that urban-rural income convergence is a complex process that involved economic, social and environmental issues on regional, national and international level. The stable and continuous tendency of urban-rural income convergence that results in diminishing income gap illustrates the income equality and equal options to live despite actual regional location.

The results of direct and indirect impacts of the first scenario argue that the total final demand expenditures of households increase by $4.5 \%$ but the national output by $2.7 \%$. The largest changes by industries/products are increase of output of Chemicals and chemical products $(8.9 \%)$, Paper and paper products $(8.7 \%)$, Electrical equipment (6.2\%), Basic pharmaceutical products and pharmaceutical preparations (6.1\%), Textiles, wearing apparel and leather products (5.8\%). The results of the second scenario argue that output increases by $3 \%$.

These results suggest that the increase and convergence of income in rural areas are important and essential process even in advanced economies, as the EU countries, the obtained modelling results certify it. The results indicate that national and EU policies are welcome and can give notable impact on national economic output and growth.

\section{References}

1. Dijkstra, L., \& Poelman, H. (2014). A harmonised definition of cities and rural areas: The new degree of urbanisation. European Commission Directorate - General for Regional and Urban Policy. Retrieved March 2, 2019, from http://ec.europa.eu/regional_policy/sources/docgener/work/2014_01_new_urban.pdf.

2. Breau, S., \& Saillant, R. (2016). Regional income disparities in Canada: Exploring the geographical dimensions of an old debate. Regional Studies, Regional Science, 3(1), 463-481. DOI: $10.1080 / 21681376.2016 .1244774$.

3. Central Statistical Bureau of Latvia . (2019, February 18). Population of rural/urban areas by sex; at the beginning of the year. Retrieved March 2, 2019, from https://data1.csb.gov.lv/pxweb/en/iedz/iedz iedzskaits_ikgad/ISG030.px/table/tableViewLayout1/?rxid=d4a4529e-e4b0-4ddd-ad8e-838a89192592.

4. Chen, F., \& Sun, X. (2014). Urban-rural income polarization and economic growth in China: Evidence from the analysis of a dynamic panel data model. Applied Economics, 46(32), 4008-4023. DOI: 10.1080/00036846.2014.950792.

5. Eurostat. (2017, September 27). Median saving rate by degree of urbanisation - experimental statistics. Retrieved March 2, 2019, from https://ec.europa.eu/eurostat/web/products-datasets/-/icw_sr_13.

6. Eurostat. (2019, February 18). Distribution of population by degree of urbanisation, dwelling type and income group - EU-SILC survey [ilc_lvho01]. Distribution of population by degree of urbanisation, dwelling type and income group - EU-SILC survey [ilc_lvho01]. Retrieved March 2, 2019, from https://ec.europa.eu/eurostat/web/cities/data/database.

7. Eurostat. (2019, February 18). Eurostat Statistics Explained. Degree of urbanisation. Retrieved March 2 , 2019, from https://ec.europa.eu/eurostat/statistics-explained/index.php/Glossary.

8. Prodromidis, P. (2008). Modelling local income distribution in Greece. Contributions to Economics, $73-97$.

9. Sicular, T., Ximing, Y., Gustafsson, B., \& Shi, L. (2007). The urban-rural income gap and inequality in China. Review of Income and Wealth, 53(1), 93-126. DOI: 10.1111/j.1475-4991.2007.00219.x.

10. Statistics Estonia. (2019, February 19). Statistics Estonia. PO0241: POPULATION, 1 JANUARY by Administrative unit or type of settlement. Retrieved March 2, 2019, from http://pub.stat.ee/px-web.2001/ dialog/SaveShow.asp.

11. Statistics Lithuania. (2019). Database of Indicators. Resident population at the beginning of the year. Retrieved February 18, 2019, from https://osp.stat.gov.lt/en_GB/statistiniu-rodikliu-analize\#/.

12. Young, A. (2013). Inequality, the urban-rural gap, and migration. Inequality, the urban-rural gap, and migration, 128(4), 1727-1785. DOI: 10.1093/qje/qjt025.

13. Zhang, H., Chen, W., \& Zhang, J. (2012). Urban-rural income disparities and development in a panel data set of China for the period from 1978 to 2006. Applied Economics, 44(21), 2717-2728. DOI: 10.1080/00036846.2011.566197. 